\title{
A Brief Overview of International Migration Motives and Impacts, with Specific Reference to FDI
}

\author{
Masood Gheasi ${ }^{1, *}$ and Peter Nijkamp ${ }^{1,2}$ \\ 1 Faculty of Economics and Business Administration, Vrije University of Amsterdam, 1081 Amsterdam, \\ The Netherlands; pnijkamp@hotmail.com \\ 2 Department of Geography, Adam Mickiewicz University, 61-712 Poznan, Poland \\ * Correspondence: m.gheasi@vu.nl
}

Academic Editor: Jacques Poot

Received: 16 November 2015; Accepted: 3 August 2017; Published: 21 August 2017

\begin{abstract}
International migration has become one of the most debated topics in many developed and developing countries. Host countries are concerned about the socioeconomic consequences of international migration, while sending countries-from a developing country's perspective-are concerned about the brain drain and loss of their younger population. This paper presents a concise literature review on existing theories of international migration, and long-run effects of international migration on Foreign Direct Investment (FDI). The empirical studies reviewed in this paper indicate a positive and statistically significant relationship between international migration and FDI.
\end{abstract}

Keywords: international migration; foreign direct investment (FDI)

JEL Classification: F21, F22

\section{Introduction}

One of the most important issues that has affected our world in recent decades is globalization, in the form of free trade and open borders for people, capital, and ideas. People's movements from one country - or even continent-to another have had a significant impact on the flow of ideas, innovation, economic development, trade, and investments. This spread of ideas and knowledge is vital for the new economic landscape of the world. However, the recent rapid increase in the number of foreign-born people and the massive waves of migrants have led to heated debates in many developed countries regarding the impact of immigrants and the subsequent social and economic shocks in host countries (see also the comprehensive study of Nijkamp et al. 2012, on migration impact assessment). Migrant sending countries are also concerned about the loss of their working population, and on the effect of brain drain.

Nowadays, on the global scale-due to political unrest in many developing countries-there has been an increase in the number of sending and receiving countries (see also Figure 1). For example, in Europe, some countries (e.g., Italy, Spain, Portugal) which for centuries were characterized as migrant sending countries, suddenly changed into major migrant-receiving countries. The receiving countries experience not only specific forms of migration (e.g., asylum seekers, temporary and permanent resettlers, economic migrants, labor migrants, knowledge migrants, tourists who became permanent residents, social migrants, international students, etc.), but also many different types of immigration at the same time. This has presented series challenges for policymakers aiming to develop a balanced form of migration policy, but has also fueled heated political debates on the desirability or acceptability of migrants. In light of the current situation, some scholars argue that we are living in an 'age of migration' (Nijkamp et al. 2011; Goldin et al. 2011). 
The UN Population Division has reported that as of the year 2013,3.2\% of the world's population lives outside their country of origin, which is an increase of 33\% compared to the year 2000. European countries host a large number of such migrants, reaching a total of 72 million (United Nations 2013).

The composition of migrants by personal characteristics (gender, age, education, skill), culture, and socioeconomic characteristics differ substantially from the population in the country of residence. They concentrate more in metropolitan areas with higher agglomeration advantages, tend to be in the most active working ages (24-49), and have often a higher education, while in some cases the proportion of women in the migration flow has also increased (Widmaier and Dumont 2011). Furthermore, recent migration policy shows that changes in the immigration points system, for which Australia and Canada are well-known, are designed to facilitate the flow of highly educated and skilled migrants, and to increase the legal barriers for low-skilled migrants. According to Docquier and Marfouk (2004), the number of highly skilled immigrants (foreign-born individuals with tertiary education) living in an OECD country increased by $70 \%$ between 1990 and 2000, while the number of low-skilled immigrants increased at a slower pace of $28 \%$ for the same period.

World Migration Stock (millions)

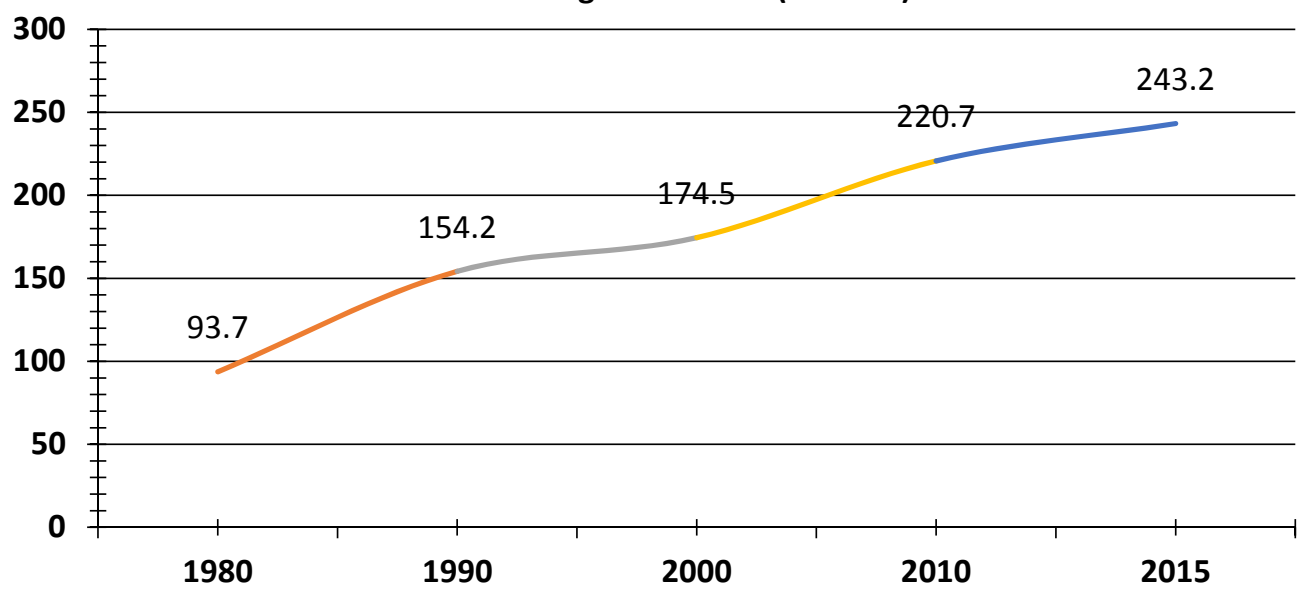

Figure 1. World Bank figures on international migration. Data source: The Wrold Bank (2016), International Migrant Stock.

Migrant sending countries are more concerned about the brain drain effect, and the loss of their talented and young workforce. However, studies of the economic impact on sending countries (developing countries) have shown that increasing emigration may be used to develop diasporas, thus giving the countries of origin inter alia the opportunity to foster economic development through different channels such as: remittances, FDI, bilateral and international trade, etc. (De Haas and Plug 2006; Gamlen 2006). This holds especially true for those countries that allow their diasporas to obtain dual citizenship.

In receiving countries, public opinion has sometimes turned against migration, and most developed countries are concerned about the economic externalities of migrants on native capital, labor markets, wages, and public finance (social benefits). Many policymakers in these developed countries believe that immigration is an economic burden, because immigrants may create social tension and increase criminality (UNDP 2009). However, international immigration has had a substantial impact on the cultural diversity and socioeconomic enrichment in many developed countries in terms of an increase of social capital, the diasporas' contribution to innovation, and the intensification of international linkages through trade and foreign direct investment, so that the host societies can benefit from the stock of diasporas in their societies.

To recognize the socioeconomic impact of migrants in a country, we need rational and scientific evidence-based studies to monitor and to identify the economic elements of international migration that play a significant role. The paper aims to present a concise overview of international migration motives 
and impacts, with specific reference to FDI. International migration is a very complex phenomenon. We will zoom in here on the socioeconomic impacts; an examination of all cultural, environmental, and political issues goes beyond the scope of this paper.

\section{Reasons to Migrate: Existing Theories of Migration}

In the history of economic thinking on why people migrate, a wide variety of approaches have been developed. Here we provide a concise and selective review of some theoretical/empirical theories.

Neoclassical macroeconomic and microeconomic theories attempt to explain inter alia the mechanism of labor migration. The first (neoclassical macroeconomic) framework indicates that migration happens as a result of a process of economic development (see, for example, Harris and Todaro 1970) and wage differences. According to this theory, individuals try to maximize their income; therefore, they migrate to regions with higher wages. The country of origin also enjoys benefits: firstly, migrants reduce the ratio of labor to capital; and, secondly, migrants make up for their absence by sending remittances to their home country. In the long run, the decline in the labor-capital ratio would remove the incentives for migration. Next, neoclassical microeconomic theory assumes that labor migration happens not only because of wage differences, but also because migrants take a rational cost-benefit decision. This cost-benefit estimation relates to the personal intention and personal characteristics ${ }^{1}$ — such as age, gender, etc.-deciding whether to migrate or not, while it also relates to the choice of alternative destinations. Apart from wage differences and employment opportunities, migration behavior also includes financial costs such as: travel cost; the period of unemployment in the destination country; and psychological costs (leaving family and friends) (Bauer and Zimmermann 1998). Thus, the greater the differences in expected returns to migration between the country of origin and the country of destination, the larger the dimension of migration flows will be.

Mass migration not only occurs due to wage differences, as neoclassical economists tend to believe-as a mechanism of international price equalization between rich and poor regions or countries-but also due to other numerous factors that sociologists identify in the form of push and pull factors. Push factors, such as natural disasters, civil wars, conflict, etc., have forced millions of people to move from their country of origin to other countries. Pull factors include higher standards of living, better employment opportunities, a better educational system etc., all of which attract people from their country of origin to the host country. This model has become the dominant model in the migration literature, because it incorporates not only the important factors that have any impact on migration decision-making, but is also able to integrate other theoretical insights (De Haas 2010). However, there are certain migration issues that this theory cannot explain; for example, why some regions produce more migrants than others, and why the direction of migration flows is often inconclusive.

The new economics of migration theory indicates that migration is a family-based decision, and people migrate not only to maximize their income, but also to minimize their migration risks (Stark and Bloom 1985; Stark 1991). Unlike individuals, families are in a position to control the risk inside their households by diversifying the allocation of household resources. For example, a family will probably send the physically-able members of their family abroad for work, and invest in higher education of the others. If the higher education inside the country does not pay off, they can rely on the remittances from the others who are working abroad. Therefore, families in developing and less developed countries tend to be large, because they are able to manage their risks by having many children. Moreover, in contrast to the neoclassical theory of migration where return migration is considered as a 'failure' factor, in the new economics of migration theory the returnees are considered a 'success' factor, because those who achieved a maximum benefit from his/her migration behavior return home with accumulated savings or knowledge (Cassarino 2004). This theory is not without

1 The likelihood of migration decreases with age, and increases with higher education. Therefore, personal characteristics also play a significant role in migration. 
criticism, as there are three major weak points in this theory: first, this theory focuses very much on the supply side of the labor migration, and ignores the demand side; second, from an operational perspective, it fits better in poor and underdeveloped regions than wealthy and urban areas; and, third, it is unable to explain why an entire family decides to migrate.

Apart from the abovementioned theories, several decades ago Piore (1979) introduced the dual labor market theory. This theory argues that it is not the push factors (low wages) that cause people to migrate, but the pull factors that cause internal and international migration. Nowadays, various developed countries are in desperate need of unskilled and cheap migrants, because of labor market changes (the high participation of women in full-time and part-time jobs, higher education, etc.) and demographic changes (concerning single parents, divorced, elderly people, etc.). These jobs are located at the bottom of the social hierarchy and are low-paying jobs in which natives are not interested. Therefore, low-skilled (and mostly undocumented) migrants have often filled such vacant positions.

An important aspect of international migration is the direction of migration flows (Tranos et al. 2015). Factors such as postcolonial ties, language, cultural similarity, etc. can cause considerable migration flows. Migrants from countries that were colonized by a host society can adapt to the host society very rapidly, because of their common language and the possibility of having friends and relatives in the host society. Moreover, once migrants establish their network-a set of interpersonal ties that connect migrants - in the host society, their network acts as a pull factor for families and relatives from the same ethnic group, encouraging them to migrate to this particular host country rather than to pursue alternative options. Through their established network, migrants are able to increase the expected return to migration by accessing the experience and social capital of their former ethnic group members. However, strong push and pull factors (e.g., high transportation costs, environmental conditions, political conditions, etc.) may also have an impact on the decision to move to a new place.

Migration systems theory incorporates many of the characteristics of the causation and effectuation of international migration indicated above, and suggests that migration flows acquire a measure of stability and structure over space and time, allowing for the identification of stable international migration systems. The word "systems" in this theory refers to the exchange of goods, capital, people, services, and information between countries (Boyd 1989; Fawcett 1989). This theory integrates the macroeconomic and microeconomic processes, and considers migration as a dynamic process where regions and countries are connected by numerous types of linkages. Therefore, migration research involves a broader intellectual discussion that includes: individuals and households (related to the migration decision), and economic, social, environmental, and political circumstances. Massey et al. (1993, p. 454) group the hypotheses and propositions of this theory as follows: "1. Countries within a system need not be geographically close since flows reflect political and economic relationships rather than physical ones. Although proximity obviously facilitates the formation of exchange relationships, it does not guarantee them nor does distance preclude them; 2. Multipolar systems are possible, whereby a set of dispersed core countries receive immigrants from a set of overlapping sending nations; 3. Nations may belong to more than one migration system, but multiple membership is more common among sending than receiving nations; 4 . As political and economic conditions change, systems evolve, so that stability does not imply a fixed structure. Countries may join or drop out of a system in response to social change, economic fluctuations, or political upheaval." In general, this theory helps us to understand how migration evolves over time and changes in magnitude, destinations, and selectivity (De Haas 2010).

The theoretical discussion on human mobility expands rapidly, but there is not a single theory that can cover the full complexity of migration flows. The increase in the diversity of migration in our expanding global economy has made the nature of migration more complex in all aspects-motivation for migration, and types of migrants (students, workers, tourists, etc.).

Two new theoretical approaches were presented by Castles (2010), Faist (2010), and Portes (2010). The first approach studies migration from the perspective of social change and social transformation, and presents a theory that migration is not only affected by the dynamics of national and global 
transformation, but is in fact a part of these changes. A clear contrast between the opinion of Castles and Portes can be observed. For Castles (2010), migration is a part of a social and institutional transformation, and of the global economy, and he pushes migration studies towards an interdisciplinary approach where it should cover wider social theories and social science disciplines. On the other hand, Portes (2010) observes that the impacts of migration on receiving societies are significant, but not deep, and suggests that migrants leave the existing social order somehow untouched.

The second approach has been widely "influenced by qualitative sociology, anthropology, human geography and culture studies, and many of these new insights reflect the widespread 'cultural turn' in social sciences" (King 2012, p. 24). This new insight however, could not bring about a new perspective on the causes of migration, though it increased our understanding of migrants' experiences.

\section{Social and Economic Impacts of Migrants}

There is also a large body of literature (with different methodological approaches) on the socioeconomic impact of immigrants in host societies, which continues to grow. Nijkamp et al. (2011, p. 361) sum up the main findings from the vast number of studies, as " ... migrants tend to have a neutral or modest positive effect on local labor markets, regional development, and spatial distribution". Furthermore, immigrants also have a significant impact on the socioeconomic condition of their country of origin. For example, the positive impact of remittances on the socioeconomic development of the country of origin is a well-studied subject in migration literature. The evidence indicates that remittances have raised internal consumption, increased local investment, and prolonged education attainment (Page and Plaza 2006).

Migration can be a self-selected or non-self-selected movement. However, self-selected movement plays a dominant role in migration flows (Borjas 1988). Therefore, migrants are not evenly distributed across countries, and even inside a host country. From a residential perspective, migrants tend to concentrate more in urban, agglomerated areas, and places where they have already established a strong network (often called ethnic precincts or ethnic enclaves) (Edin et al. 2003), and, through their network connections, they reduce migration costs. These not only hold for labor migrants; such a clustering effect can also be observed in other types of immigration, such as: business migrants, international students, lifestyle migrants, etc. This leads to the need to measure the socioeconomic impact of immigration at different geographical levels (e.g., local, regional, national, and global). Among the different geographical dimensions, the national level has received considerable attention compared to local and regional levels. From a global perspective, it is indicated that completely opening up borders could add more to the global output than trade liberalization (Goldin et al. 2011).

The socioeconomic impact of migrants can be divided into two types of effects: direct effects (e.g., tax payment, unemployment benefits, increase in consumption, etc.); and indirect effects (international trade, foreign direct investment, etc.). The impacts can have short-run or long-run effects on the countries of origin and destination. Nijkamp et al. (2011) present a detailed classification of these short-run or long-run impacts, and divide them into two major classes: the micro-effects on the country of origin/destination/both, and the meso/macro-effects on the country of origin/destination/both. As migration is a complicated phenomenon, these classifications can help us to form a two-by-two way of economic analysis of migration, even if they are unable to present an obvious division, because some short-run impacts can have a permanent effect, such as path-dependency (Nijkamp et al. 2011).

Nowadays, migration has a deeply-rooted impact on both sending and receiving countries. It has not only changed the social and cultural structure of many migrant-receiving societies, but it has also had a significant impact on wider economic activities. These impacts can be observed from two perspectives; first, the impact of migrants on host societies; and second, the impact of diasporas on the social and economic development of their countries of origin. From the receiving societies' perspective, nowadays significant shares of migrant-receiving societies' economic activities-especially low-cost sectors such as food processing, elderly care, domestic work, etc.-depend on migrants. The net 
gain in migrant transfers can wipe-out low-skilled natives from the low-skilled sectors. Furthermore, migrants can also act as a bridge of information between their countries of origin and host countries. By observing this effect, one can easily assume that an increase in the number of migrants can incite flows of capital in the form of Foreign Direct Investment (FDI), tourist flows, and international trade. In the next section, we discuss some of the long-run impact factors of international migration on sending and host areas.

Agglomeration: In contrast to previous theories of international trade, New economic geography theories explain that regions with specific characteristics-e.g., low trade barriers, high-tech industries, etc.-may induce agglomeration, and as a consequence may attract both capital and labor flows. If we accept that the flow of migrants complements the flow of capital, and that the impact of higher educated and skilled migrants would be higher, then agglomeration increases the brain drain effect from poor countries to richer ones. Meanwhile, for receiving countries, it may create more skill-intensive technologies and may boost employment and economic growth.

Networking: Migrants may be strongly involved in trading and investing in their home country; this factor can have a significant impact on boosting international trade and foreign capital inflows, thanks to their inside knowledge or their social ties. Gould's (1994) work, amongst others, brought the network effect of migrants into play, and indicated that migrants affect trade through two channels: first, the demand for home-country products-assuming this is based on the assumption that a rise in the number of migrants leads to more imports-and, second, the effect of a migrants' network in lowering the trade costs between their countries of origin and destination. Therefore, the costs of international trade and foreign direct investment cannot be simply explained by the factors of geographical distance and socioeconomic development, but also by costs related to the lack of information. In this regard, migrants with their indigenous knowledge of their countries of origin-language, trust level, knowledge on institutional structures, contracts, etc.- - may reduce the information costs and boost international trade and foreign direct investment (see also Genc et al. 2012).

Education and skill level: Selective migration policies in many developed countries have increased the ability — the race for talent—-to attract highly educated (skilled) migrants. These selective migration programs serve as tools to gain a competitive advantage in the global economy. Estimates from developing countries show that $41 \%$ of tertiary educated workers from Caribbean countries live in OECD countries (Docquier and Marfouk 2005). Given the impact of immigrants on FDI, it is assumed that highly educated (skilled) migrants would have a particularly large impact on the flow of capital between the country of origin and destination, since educated migrants have accurate knowledge of the chances and risks of investment in their country of origin. This is very crucial market information for foreign investors, and skilled migrants also have the talent to work for foreign investors in their countries of origin-evidence from China and India shows that multinational firms have recruited knowledge diasporas as senior personnel in those countries. However, it is also important to note that a reverse causality effect exists between migration, trade, and FDI, as migrants can have an impact on the inward and outward flows of FDI, while the inward flow of FDI can also have an impact on international migration. Empirical studies have mostly tackled this double-causality issue through an instrumental variables (IV) model (see for example, Javorcik et al. 2011).

The detailed analysis of all social and economic impacts of migrants is a very broad topic and falls outside the scope of this paper. Therefore, among the complex and broad socioeconomic impacts of migration, we focus on a specific impact category, viz the impact of migrants on FDI. Below, we present some empirical findings on the abovementioned link.

\section{Empirical Findings on Foreign Direct Investment}

In our globalized world, where two crucial factors of production-capital and labor-are mobile, immigrants play a crucial role in reducing information asymmetries between a country of origin and destination. This is in contrast to the neoclassical theory of trade and growth, which suggests an inverse 
relationship between capital and labor. Based on the neoclassical theory, regions or countries where the labor cost is lower attract more investments, while places with higher wages receive more workers.

Given the statistical figures from many developed countries that indicate that the flow of both labor and capital is higher in developed countries in comparison with poor countries, Lucas (1990) tried to explain the reason for a higher concentration of both capital and labor in rich countries by skill differences. He found that differences in skill levels of labor could generate different returns to capital across countries. However, investment can be a risky business, which highly depends on a number of factors such as security, political stability, good governance, rule of law, institutions, corruption, etc. Therefore, it generally requires a long-term focus and interaction with different groups of people (e.g., workers, government employees), and detailed knowledge of legal and regulatory regimes, business culture, consumers, etc. Taking into account the information costs and risks mentioned above, one could assume a positive association between the stock of migrants and inward and outward FDI. In this regard, highly educated and skilled migrants bring with them not only more knowledge about the social, legal, and economic structure of their countries of origin, but also their social network which incorporates important information for investors.

A growing body of literature on the impact of migrants on FDI has addressed the complementarity and substitution effect of migration with FDI. Table 1 below presents a list of publications and the impact of migration on FDI. In general, there is a positive and statistically significant impact of migration on FDI; however, there are some differences regarding the education and skill level of migrants. Some authors found a positive and significant impact of highly educated migrants on FDI (Foley and Kerr 2008; Kugler and Rapoport 2007; Gheasi et al. 2011), while others found a negative and significant impact (Aroca and Maloney 2005; Foad 2011). However, Foad (2011) relates his negative and statistically significant finding for college migrants to the nationality of those migrants. It seems that skilled and educated migrants have a significant impact on the facilitation of FDI, and unskilled and poorly educated migrants substitute FDI flows.

Table 1. The effect of immigration on FDI in various empirical studies.

\begin{tabular}{|c|c|c|c|}
\hline Study & Sample & Outward FDI (Elasticity) & Inward FDI (Elasticity) \\
\hline Tong (2005) & $\begin{array}{c}\text { Ethnic Chinese and FDI } \\
\text { position between } 70 \text { countries, } \\
1990\end{array}$ & $0.19^{* * *}$ & $0.19^{* * *}$ \\
\hline Buch et al. (2005) & 16 German states; $1990-2000$ & $\begin{array}{c}0.01 \text { (net stocks) } \\
0.48^{* *} \text { (gross stocks) }\end{array}$ & $\begin{array}{c}0.06^{* *} \text { (net stocks) } \\
-0.10 \text { (gross stocks) }\end{array}$ \\
\hline Kugler and Rapoport (2007) & US outflows; 1990 and 2000 & $\begin{array}{c}0.22 *\left(\text { primary }^{1}\right) \\
-0.56\left(\text { secondary }^{2}\right) \\
0.44 * *\left(\text { tertiary }^{3}\right)\end{array}$ & NA \\
\hline \multirow{2}{*}{ Bhattacharya and Groznik (2008) } & $\begin{array}{l}\text { Model A: US with } 33 \text { countries; } \\
\text { 1970, 1980, } 1990 \text { and } 2000\end{array}$ & $0.33^{* *}$ & NA \\
\hline & $\begin{array}{l}\text { Model B: US with } 36 \text { countries; } \\
1970,1980,1990 \text { and } 2000\end{array}$ & $0.42^{* *}$ & NA \\
\hline Javorcik et al. (2011) & $\begin{array}{l}\text { US with } 56 \text { countries; } \\
1990 \text { and } 2000\end{array}$ & $\begin{array}{c}0.35^{* * *} \& 0.42^{* * *}(\text { stock }) \\
0.41^{* * *} \& 0.52^{* * *} \text { (tertiary }^{3} \text { ) }\end{array}$ & NA \\
\hline Nijkamp et al. (2011) & $\begin{array}{l}\text { Meta-analysis on nine research } \\
\text { articles (three published, and } \\
\text { six unpublished) }\end{array}$ & $\begin{array}{c}0.076\left(\text { tertiary }^{3}\right) \\
-1.172^{* * *}\left(\text { primary }^{1}\right) \\
0.136(\text { skilled }) \\
-0.342^{* * *}(\text { low-skilled })\end{array}$ & $\begin{array}{c}1.467^{* * *}\left(\text { tertiary }^{3}\right) \\
-0.901^{* * *}\left(\text { primary }^{1}\right) \\
0.717^{* * *}(\text { skilled }) \\
-0.520^{* *}(\text { low-skilled }) \\
\end{array}$ \\
\hline \multirow[t]{2}{*}{ Foad (2011) } & \multirow{2}{*}{$\begin{array}{l}50 \text { US states with } 10 \text { source } \\
\text { countries; } 1990 \text { and } 2000\end{array}$} & & $\begin{array}{c}\text { Affiliates } \\
0.06^{* *} \\
78.462^{* *}(\text { diaspora stock }) \\
-0.833^{* *}(\text { college }) \\
-0.584^{* *}(\text { diaspora college })\end{array}$ \\
\hline & & & $\begin{array}{c}\text { Gross property } \\
0.010 \\
10.877^{* *}(\text { diaspora stock) } \\
-0.004 \text { (college) } \\
0.017 \text { (diaspora college) }\end{array}$ \\
\hline
\end{tabular}


Table 1. Cont.

\begin{tabular}{|c|c|c|c|}
\hline Study & Sample & Outward FDI (Elasticity) & Inward FDI (Elasticity) \\
\hline \multirow{5}{*}{ Flisi and Murat (2011) } & France 1990, 1999 & $\begin{array}{c}0.069 \text { (low-skilled) } \\
0.610 \text { (skilled OECD) } \\
0.647 \text { (skilled non-OECD) }\end{array}$ & $\begin{array}{c}-0.615 \text { (low-skilled) } \\
\left.1.754^{* * *} \text { (skilled OECD }\right) \\
1.277^{* * *} \text { (skilled non-OECD) }\end{array}$ \\
\hline & Germany 1991-2006 & $\begin{array}{c}0.002 \text { (low-skilled) } \\
0.368 \text { (skilled OECD) } \\
0.452^{* *} \text { (skilled non-OECD) }\end{array}$ & $\begin{array}{c}-0.484 *(\text { low-skilled }) \\
1.243 * * * \text { (skilled OECD }) \\
0.776 *(\text { skilled non-OECD })\end{array}$ \\
\hline & Italy 2002-2005 & $\begin{array}{c}0.163 \text { (low-skilled) } \\
-0.253 \text { (skilled OECD) } \\
0.063 \text { (skilled non-OECD) }\end{array}$ & $\begin{array}{c}-0.228 \text { (low-skilled) } \\
0.017 \text { (skilled OECD } \\
0.201 \text { (skilled non-OECD) }\end{array}$ \\
\hline & Spain 2003-2006 & $\begin{array}{c}-0.669 \text { (low-skilled }) \\
1.232 *(\text { skilled OECD }) \\
0.979 \text { (skilled non-OECD })\end{array}$ & $\begin{array}{c}-1.453^{* * *} \text { (low-skilled) } \\
1.598^{* *} \text { (skilled OECD) } \\
1.414^{*} \text { (skilled non-OECD) }\end{array}$ \\
\hline & UK 1990, 1995, 2001 & $\begin{array}{c}-0.769 *(\text { low-skilled }) \\
1.703^{* *}(\text { skilled OECD }) \\
1.648^{* * *}(\text { skilled non-OECD })\end{array}$ & $\begin{array}{c}-0.630 \text { (low-skilled) } \\
0.780 \text { (skilled OECD) } \\
2.603^{* *} \text { (skilled non-OECD) }\end{array}$ \\
\hline Gheasi et al. (2013) & $\begin{array}{l}\text { UK with } 22 \text { countries for } \\
\text { inward FDI; 2001-2007 } \\
\text { UK with } 27 \text { countries for } \\
\text { outward FDI; } 2001-2007\end{array}$ & $\begin{array}{c}0.609^{* * *} \& 0.330^{* *}(\text { stock }) \\
1.263^{* * *} \& 1.1003^{* * *}\left(\text { higher education }^{3}\right) \\
-0.431^{* * *} \&-0.410^{* *}\left(\text { lower education }^{1}\right)\end{array}$ & $\begin{array}{c}-0.114 \&-0.110 \text { (stock) } \\
1.235^{* * *} \& 2.937 \text { (higher education }{ }^{3} \text { ) } \\
-0.706^{* * *} \&-1.607 \text { (lower education }{ }^{1} \text { ) }\end{array}$ \\
\hline Aubry et al. (2016) & $\begin{array}{l}\text { Average FDI position for } \\
\text { pair of countries from } \\
2001 \text { to } 2006 .\end{array}$ & $\begin{array}{r}0.190^{* * *} \text { (to } \\
0.243^{* * *} \text { (high-s } \\
0.195^{* * *} \text { (low-s }\end{array}$ & $\begin{array}{l}\text { l migration) } \\
\text { illed migration) } \\
\text { lled migration) }\end{array}$ \\
\hline
\end{tabular}

*** significant at $1 \%,{ }^{* *}$ significant at $5 \%$ and ${ }^{*}$ significant at $10 \% .{ }^{1}$ migrants with primary education; ${ }^{2}$ migrants with secondary education; ${ }^{3}$ migrants with tertiary education.

For poorly educated migrants, a different mechanism seems to play a role; the empirical evidence indicates that poorly educated (low-skilled) migrants partially substitute for FDI (Kugler and Rapoport 2007; Gheasi et al. 2013). Moreover, Kugler et al. (2017) investigated the role of migrants in alleviating informational asymmetries to financial investments and international financial flows. They found that migration has a positive and statistically significant impact on international bank lending and this effect is stronger in the case of skilled migrants. Aubry et al. (2016) estimated the relationship between trade, migration, and FDI in the context of firms' heterogeneity, and they found that migration and in particular skilled migrants have a positive impact on trade and FDI, but the effect is more pronounced on FDI.

\section{Conclusions}

Globalization and free movement among developed countries have had a significant impact on cross-border migration, capital mobility, innovation, and economic development. The recent mass migration has created heated debates, and has generated both supporters and opponents inside host societies. There is no doubt that migration has affected host and sending economies in different ways. This study has tried to observe the long-term impact of immigration on FDI. As indicated above, migrants are heterogeneous groups and their personal characteristics such as age, education, and gender differ significantly from the population of the host society. Therefore, their impact on FDI can have different forms. We have demonstrated in particular the economic externalities of immigrants with different education and skill levels on FDI.

The newly arrived migrants in Europe are mostly educated people, and their education costs have usually been financed by the country of origin. This is a huge economic benefit to receiving countries and this flow may bring long-term economic benefits, if they are given a chance to serve as workers. The literature on the innovation and productivity of firms indicates that firms with culturally diverse employees are more innovative compared to firms with homogeneous employees. As a consequence of recent massive waves of refuges and migrants in Europe, a cultural revolution is foreseeable that may change the entire social structure of European societies.

It is important to indicate that the long-term effects of migration on FDI is positive and significant. This means that careful empirical research results obtained from one European country has a potential for generalization with other European countries. For example, we have demonstrated through a 
concise literature review that a different education level of migrants has a different impact on inward and outward flows of FDI.

Migration has become a very sensitive political topic. However, it is important to convince policymakers in receiving countries that migration is in fact not a policy goal per se; it is meaningful to make a difference between the (objective) real impact of immigration and its (subjective) perceived impact. A number of scientific studies that have been conducted on the socioeconomic impact of migrants in host societies have revealed a positive correlation between the stock of immigrants and various economic activities (e.g., international trade and FDI).

Summing up, the links between migration and FDI flows are complex and difficult to understand. Therefore, there is a need further the understanding of this phenomenon in greater detail through solid, evidence-based research; policies that are targeted at only one type of migration flow also affect the others. A comprehensive migration impact assessment is therefore needed in our 'age of migration'.

Author Contributions: Masood Gheasi was responsible for conceptualizing the paper, framing its research objectives, and interpretation of migration theories; while Peter Nijkamp contributed mainly into the ensuring overall quality control of the paper.

Conflicts of Interest: The authors declare no conflicts of interest.

\section{References}

Aroca, Patricio, and William F. Maloney. 2005. Migration, trade and foreign direct investment in Mexico. World Bank Economic Review 19: 449-72. [CrossRef]

Aubry, Amandine, Hillel Rapoport, and Ariell Reshef. 2016. Migration, FDI and the Margins of Trade. New York: Mimeo, Paris: Paris School of Economics.

Bauer, Thomas K., and Klaus F. Zimmermann. 1998. Causes of international migration: A survey. In Crossing Borders: Regional and Urban Perspectives on International Migration. Edited by Cees Gorter, Peter Nijkamp and Jacques Poot. Aldershot: Ashgate, pp. 95-127.

Bhattacharya, Utpal, and Peter Groznik. 2008. Melting pot or salad bowl: some evidence from US investment aborad. Journal of Financial Markets 11: 228-58. [CrossRef]

Borjas, George J. 1988. Immigration and Self-Selection. NBER Working Papers 2566; Cambridge: National Bureau of Economic Research.

Boyd, Monica. 1989. Family and personal networks in international migration: Recent developments and new agendas. International Migration Review 23: 638-70. [CrossRef] [PubMed]

Buch, Claudia M., Jörn Kleinert, Alexander Lipponer, Farid Toubal, and Richard Baldwin. 2005. Determinants and effects of foreign direct investment: Evidence from German firm-level data. Economic Policy 20: 52-110, US ethnic scientists and foreign di. [CrossRef]

Cassarino, Jean-Pierre. 2004. Theorising return migration: The conceptual approach to return migrants revisited. International Jounral on Multicultural Scocieties 6: 253-79.

Castles, Stephen. 2010. Understanding Global Migration: A Social Transformation Perspective. Journal of Ethnic and Migration Studies 36: 1565-86. [CrossRef]

De Haas, Hein. 2010. Migration and development: A theoretical perspective. International Migration Reveiw 44: 227-64. [CrossRef] [PubMed]

De Haas, Hein, and Roald Plug. 2006. Cherishing the goose with the golden eggs: Trends in migrant remittances from Europe to Morocco 1970-2004. International Migration Review 40: 603-34. [CrossRef]

Docquier, Frédéric, and Abdeslam Marfouk. 2004. Measuring the International Mobility of Skilled Workers, 1990-2000. World Bank Policy Reseach Working Papers 3381; Washington: The World Bank.

Docquier, Frédéric, and Abdeslam Marfouk. 2005. International Migration by Educational Attainment. In International Migration, Remittances, and the Brain Drain. Edited by Caglar Özden and Maurice W. Schiff. Washington and New York: The World Bank and Palgrave Macmillan.

Edin, Per-Anders, Peter Fredriksson, and Olof Åslund. 2003. Ethnic enclaves and the economic success of immigrants-Evidence from a natural experiment. Quarterly Journal of Economics 118: 329-57. [CrossRef]

Faist, Thomas. 2010. Towards Transnational Studies: World Theories, Transnationalisation and Changing Institutions. Journal of Ethnic and Migration Studies 36: 1665-87. [CrossRef] 
Fawcett, James T. 1989. Networks, linkages, and migration systems. Nternational Migration Review 23: 671-88. [CrossRef]

Flisi, Sara, and Marina Murat. 2011. The hub continent. Immigrant networks, emigrant diasporas and FDI. The Journal of Socio-Economics 40: 796-805. [CrossRef]

Foad, Hisham. 2011. FDI and immigration: A regional analysis. The Annals of Regional Science. [CrossRef]

Foley, C.F, and William R. Kerr. 2008. US Ethnic Scientists and Foreign Direct Investments Placement. Working Paper 978; Boston: Harvard Business School.

Gamlen, Alan. 2006. Diaspora Engagement Policies: What Are They, and What Kinds of States Use Them? Working Paper WP-06-32; Oxford: Center on Migration, Policy and Society.

Genc, Murat, Masood Gheasi, Jacques Poot, and Peter Nijkamp. 2012. The impact of immigration on international trade: A meta-analysis. In Migration Impact Assessment: New Horizons. Edited by Peter Nijkamp, Jacques Poot and Mediha Sahin. Cheltenham: Edward Elgar Publishing Limited, pp. 301-37.

Gheasi, Masood, Peter Nijkamp, and Piet Rietveld. 2011. Migration and tourist flows. In Advances in Tourism Economics. Edited by Álvaro Matias, Peter Nijkamp and Manuela Sarmento. Heidelberg: Physika-Verlag, pp. 111-26.

Gheasi, Masood, Peter Nijkamp, and Piet Rietveld. 2013. Migration and foreign direct investment: Education matters. Annals of Regional Science 51: 73-87. [CrossRef]

Goldin, Ian, Geoffrey Cameron, and Meera Balarajan. 2011. Exceptional People: How Migration Shaped Our World and Will Define Our Future. Princeton: Princeton University Press.

Gould, David M. 1994. Immigrant links to home country: Empirical implications for U.S. bilateral trade flows. Review of Economics and Statistics 76: 302-16. [CrossRef]

Harris, John R., and Michael P. Todaro. 1970. Migration, unemployment and development: A two-sector analysis. American Economic Review 60: 126-42.

Javorcik, Beata S., Çağlar Özdenc, Mariana Spatareanud, and Cristina Neaguc. 2011. Migrant networks and foreign direct investment. Journal of Development Economics 94: 231-41. [CrossRef]

King, Russell. 2012. Theories and Typologies of Migration: An Overview and a Primer. Willy Brandt Series of Working Papers in International Migration and Ethnic Relations Working Papers 3/12; Malmo: University Malmö.

Kugler, Maurice, and Hillel Rapoport. 2007. International labor and capital flows: Complements or substitutes? Journal of Economic Letters 94: 155-62. [CrossRef]

Kugler, M., Oren Levintal, and Hillel Rapoport. 2017. Migration and Cross-Border Financial Flows. Policy Research Working Papers 8034; Washington: The World Bank.

Lucas, Robert E. 1990. Why doesn't capital flow from rich to poor countries? The American Economic Review 80: 92-96.

Massey, Douglas S., Joaquin Arango, Graeme Hugo, Ali Kouaouci, Adela Pellegrino, and J. Edward Taylor. 1993. Theories of international migration: A review and appraisal. Population and Development Review 19: 431-66. [CrossRef]

Nijkamp, Peter, Masood Gheasi, and Piet Rietveld. 2011. Migrants and international economic linkages: A meta-overview. Spatial Economic Analysis 6: 359-76. [CrossRef]

Peter Nijkamp, Jacques Poot, and Mediha Sahin, eds. 2012. Migration Impact Assessment: New Horizons. Cheltenham: Edward Elgar.

Page, John, and Sonia Plaza. 2006. Migration, remittances and development: A review of the global evidence. Journal of African Economies 15: 245-336. [CrossRef]

Piore, Michael J. 1979. Birds of Passage: Migrant Labor and Industrial Societies. Cambridge: Cambridge University Press.

Portes, Alejandro. 2010. Migration and Social Change: Some Conceptual Reflections. Journal of Ethnic and Migration Studies 36: 1537-63. [CrossRef]

Stark, Oded. 1991. The Migration of Labor. Cambridge: Basil Blackwell Ltd.

Stark, Oded, and David E. Bloom. 1985. The new economics of labor migration. The American Economic Review 75: 173-78.

Tong, Sarah Y. 2005. Ethnic networks in FDI and the impact of institutional development. Review of Development Economics 9: 563-80. [CrossRef]

Tranos, Emmanouil, Masood Gheasi, and Peter Nijkamp. 2015. International migration: A global complex network. Environment and Planning B, Planning and Design 42: 4-22. [CrossRef] 
United Nations Development Programme (UNDP). 2009. Overcoming Barriers: Human Barriers and Development, Human Development Report. New York: UNDP.

United Nations. 2013. World Population Ageing 2013. New York: Department of Economic and Social Affairs Population Division.

Widmaier, Sarah, and Jean-Christophe Dumont. 2011. Are Recent Immigrants Different? A New Profile of Immigrants in the OECD Based on DIOC 2005/06. OECD Social, Employment and Migration Working Papers 126; Paris: OECD Social.

The Wrold Bank. 2016. International Migrant Stock, Total. Available online: http: / / data.worldbank.org/indicator/ SM.POP.TOTL?end=2015\&start=1960\&view=chart (accessed on 12 July 2017).

2017 by the authors. Licensee MDPI, Basel, Switzerland. This article is an open access article distributed under the terms and conditions of the Creative Commons Attribution (CC BY) license (http://creativecommons.org/licenses/by/4.0/). 